\title{
Article \\ (In)Equitable Accessibility to Sustainable Transport from Universities in the Guadalajara Metropolitan Area, Mexico
}

\author{
Hugo de Alba-Martínez ${ }^{1}(\mathbb{D})$, Alejandro L. Grindlay ${ }^{2}(\mathbb{D})$ and Gabriela Ochoa-Covarrubias ${ }^{3, *}$ \\ 1 Department of Technological and Industrial Processes, ITESO, the Jesuit University of Guadalajara, \\ 45604 Tlaquepaque, Mexico; hdealba@iteso.mx \\ 2 Department of Urban and Regional Planning, University of Granada, 18071 Granada, Spain; grindlay@ugr.es \\ 3 Department of Habitat and Urban Development, ITESO, the Jesuit University of Guadalajara, \\ 45604 Tlaquepaque, Mexico \\ * Correspondence: ochoagabriela@iteso.mx; Tel.: +34-651-416-116
}

Citation: de Alba-Martínez, H.; Grindlay, A.L.; Ochoa-Covarrubias, G. (In)Equitable Accessibility to Sustainable Transport from Universities in the Guadalajara Metropolitan Area, Mexico. Sustainability 2021, 13, 55. https://dx.doi.org/10.3390/su13010055

Received: 10 December 2020 Accepted: 19 December 2020 Published: 23 December 2020

Publisher's Note: MDPI stays neutral with regard to jurisdictional claims in published maps and institutional affiliations.

Copyright: (c) 2020 by the authors. Licensee MDPI, Basel, Switzerland. This article is an open access article distributed under the terms and conditions of the Creative Commons Attribution (CC BY) license (https: / / creativecommons.org/ licenses/by/4.0/).

\begin{abstract}
The equitable accessibility to higher education favours social fairness in economic opportunities. This paper provides an empirical approach to the assessment of the (in)equity of accessibility from universities to sustainable transport modes: Light Rail Transit, Bus Rapid Transit, buses, and bicycle infrastructure in the Guadalajara Metropolitan Area (Mexico). In particular, the study designed and calculated an Access to Sustainable Transport from University Index by combining governmental and crowdsourced Open Access Data. It used spatial analysis techniques within a Geographic Information Systems environment, and multivariate statistical methods such as Principal Component Analysis and Cluster Analysis. The findings highlight the weakness in the accessibility to sustainable transport modes from the universities in the Metropolitan Area. Furthermore, this study revealed an unfavourable bias in the location of sustainable transport stations/stops in the vicinity of public universities. The results provide a methodology and empirical evidence for transport policy makers to reduce inequalities and therefore transport-related social exclusion in this under-represented, but socially relevant, student community.
\end{abstract}

Keywords: accessibility; social exclusion; university; inequity; sustainable transport; principal component analysis; geographic information system; crowdsourcing; open access data

\section{Introduction}

Equitable accessibility to university facilities (UFs) guarantees social fairness in economic opportunities [1]. Students suffer transport-related social exclusion when transport services are non-existent or severely restricted [2] due, for example, to the distance to reach them [3] or the limited multi-modal transport options [4]. According to Litman [5], equity refers to the fairness with which benefits are distributed. The spatial equity of accessibility is the provision of consistent access throughout a geographic space. Since Wachs and Kumagai [6], up to the present day, the equity of accessibility has been a subject of research interest [7-10] and, more recently, public policies [11].

The literature concerning accessibility is extensive [7,8,12-18], along with empirical reviews worldwide [19-25] and in Latin America [26-39]. Nevertheless, there is no consensus on the definition of accessibility [15,40], mainly due to its relationship to the multidimensionality of transport equity. In this study, accessibility was defined as the possibility to reach a station/stop (henceforth 'node') of a sustainable transport mode from UFs. Three elements are included in this definition, i.e., the number of destinations around the UFs; the ease to reach them by walking or cycling within a walking-time threshold; and the quality of each node, as defined by the number of routes and bicycle lanes.

Access to sustainable transport mode (STM) infrastructure from universities is fundamental in order to reduce the social exclusion of students in the current era of the sustainable mobility paradigm [41]. The promotion of STMs in the vicinity of UFs, e.g., 
Light Rail Transit (LRT), Bus Rapid Transit (BRT), buses and bicycle infrastructure, greatly benefits not only the students, but the city as a whole [42]. First, students need STMs to commute to UFs, due to their limited incomes and transport choices $[43,44]$. Second, the promotion of STMs contributes to shifting the future travel behaviour of current students [45]. Third, the sustainable mobility paradigm promotes more equitable and livable cities $[41,42,46,47]$.

The sharing mobility paradigm, e.g., park and ride (PR) systems or bike-sharing systems (BSS), is growing worldwide as a solution for sustainable mobility in cities as a complete system. Macioszek and Kurek [48], and Ibrahim et al. [49] analysed the use of PR in Cracow (Poland) and Putrajaya (Malaysia), respectively, as an option for the improvement of accessibility to STM. In Warsaw (Poland), the BSS is an element enhancing sustainable mobility [50]. Politis et al. [51] studied the willingness to shift to BSS in Thessaloniki (Greece). They found that the BSS promotes sustainability because they are an active mode of transport. Moreover, in the current COVID-19 pandemic, BSS is a safe mobility option [52]. In accordance with these global trends, the individual transport systems-e.g., assisted bicycles, segways, and scooters-have been integrated into public policies in the Guadalajara Metropolitan Area (GMA), and they must operate in the city under the principles of accessibility, equity, and security [53,54]. University students transport-related inequities have been studied in developed countries [43,45,55-63]. Some authors have tackled the conceptual frame $[5,6,8,14,16,17]$, while others have improved the concepts through empirical studies worldwide $[4,60,64-67]$ and in Latin America $[34,68]$. Little scholarly research was found to have been published regarding this subject in developing countries [69-72], and very little scientific evidence was found with regard to the (in)equity of accessibility to sustainable transport means from UFs in Latin American cities. In particular, few quantitative studies have explored university students' travel needs in the Guadalajara Metropolitan Area (GMA) [73], in which the urban transport system clearly generates social inequities [74] in one of the largest metropolitan areas in Latin America [75].

The aim of this empirical study was to measure the inequity of accessibility to sustainable transport as an indicator of student transport-related social exclusion in the GMA. An Access to Sustainable Transport from University Index (ASTUI) was calculated by measuring the access, in the vicinity of UFs, to ST nodes, i.e., LRT, BRT and bicycle-sharing stations, as well as high-quality and conventional bus stops. The ST nodes were weighted by means of Principal Component Analysis. Thus, the ASTUI included the two main aspects of the broader concept of accessibility, i.e., walking/cycling distance, and the number of nodes and their quality, in terms of the quantity of the number of routes at each node.

This study provides methodological and empirical contributions. On the one hand, the methodology includes advanced spatial and statistical analyses using crowdsourced Open Access Data, i.e., data which was produced and reviewed by the community. On the other hand, it also contributes to the understanding of mobility in the GMA. The findings highlight the weakness in accessibility to sustainable transport from the universities in the metropolitan area. Furthermore, this study reveals an unfavorable bias in the location of sustainable transport stations/stops in the vicinity of public universities.

This paper includes five sections. After this introduction, Section Two describes the state of the art, the study area, the methodology, and the data for the calculations of the (in)equity of the spatial accessibility from UFs to STMs. Section Three presents the findings of horizontal and vertical (in)equity by means of maps and charts. Next, Section Four includes discussions. Finally, Section Five provides conclusions, implications and recommendations for further research.

\section{Materials and Methods}

\subsection{Study Area}

The Guadalajara Metropolitan Area (GMA) — the capital of the state of Jalisco, one of 32 states of the Mexican Republic - has 4.5 million inhabitants spread over 3365 square 
kilometres [76] (Figure 1). The GMA is served by a multimodal transport system network. In accordance with international trends, sustainable transport means are promoted by university authorities as a way to reduce environmental impacts on cities [71]. Thus, the modes of transport considered in this study were the LRT, the BRT, high-quality buses, conventional buses, and bicycles. According to the Office of Agrarian, Territorial and Urban Development (SEDATU) [77], Jalisco is among the states with the highest federal and local public investment in sustainable mobility projects, particularly in public transport (PT) and bicycle lanes.

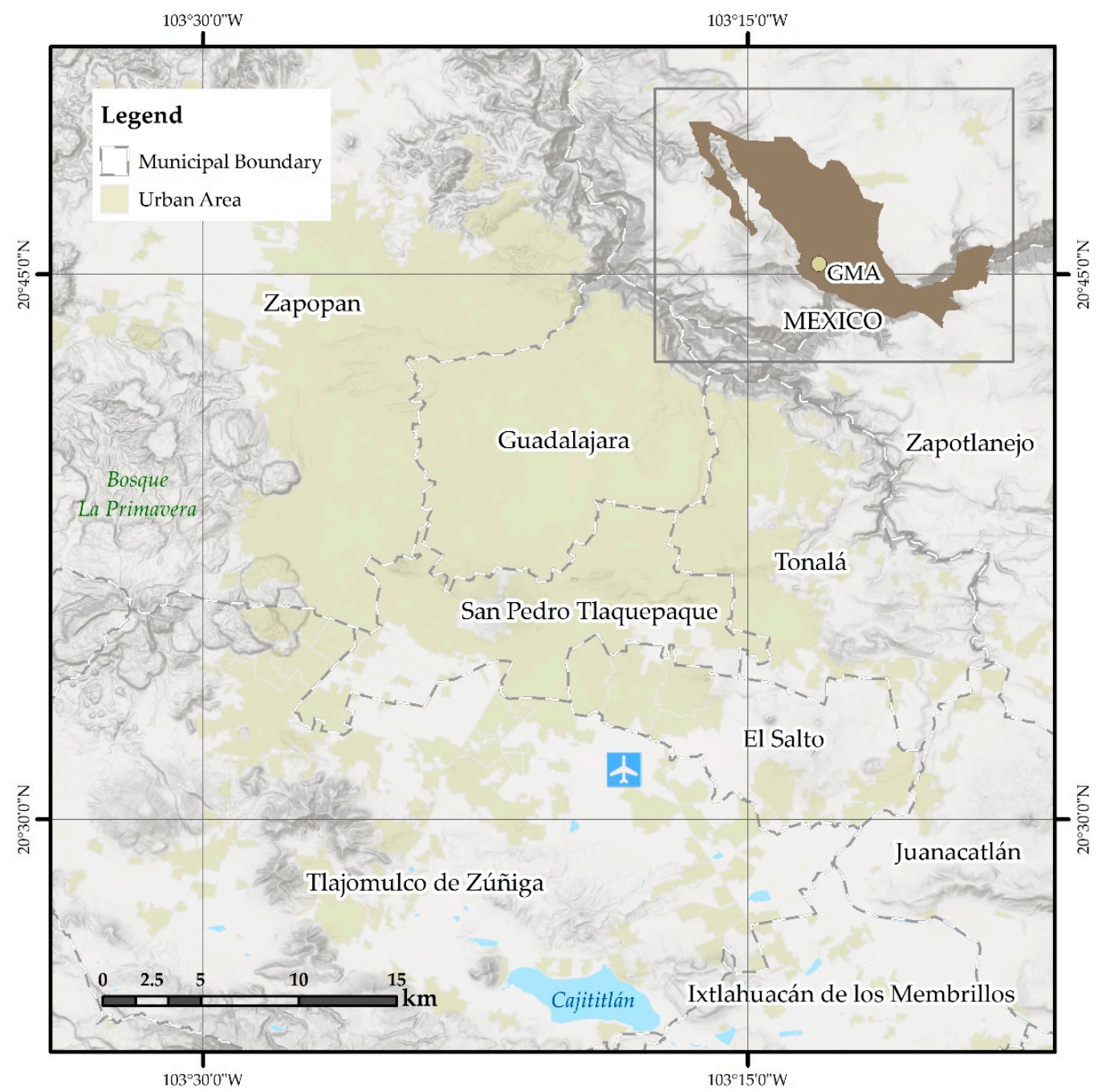

Figure 1. The Guadalajara Metropolitan Area (GMA). Source: authors, based on [78-81].

Figures 2-4 illustrate STM in the GMA. First, the mass transport system known as SITEUR (Urban Electric Train System, from its initials in Spanish) consists of three LRT lines and one BRT line (a second BRT line is currently under construction) known as Tren Ligero and Macrobús, respectively. Second, high-quality buses, known as Sitren, and conventional buses serve the city, with 255 routes in total. Third, the bicycle-sharing system, known as MiBici, encompasses 287 docking stations and a 194-km bicycle lane network. The outer suburbs are also served by other private on-demand transport modes that are beyond the scope of this study. 


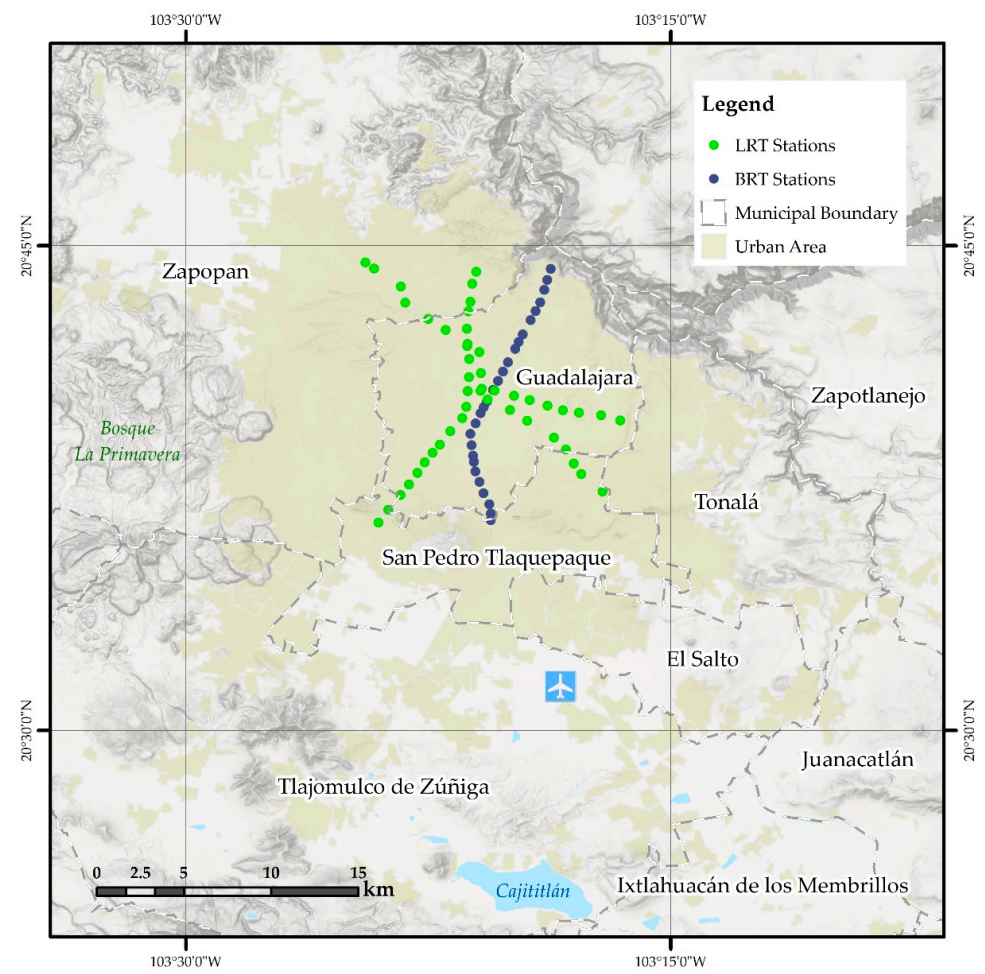

Figure 2. Mass Transport System in the Guadalajara Metropolitan Area (GMA). Source: authors, based on [78-82].

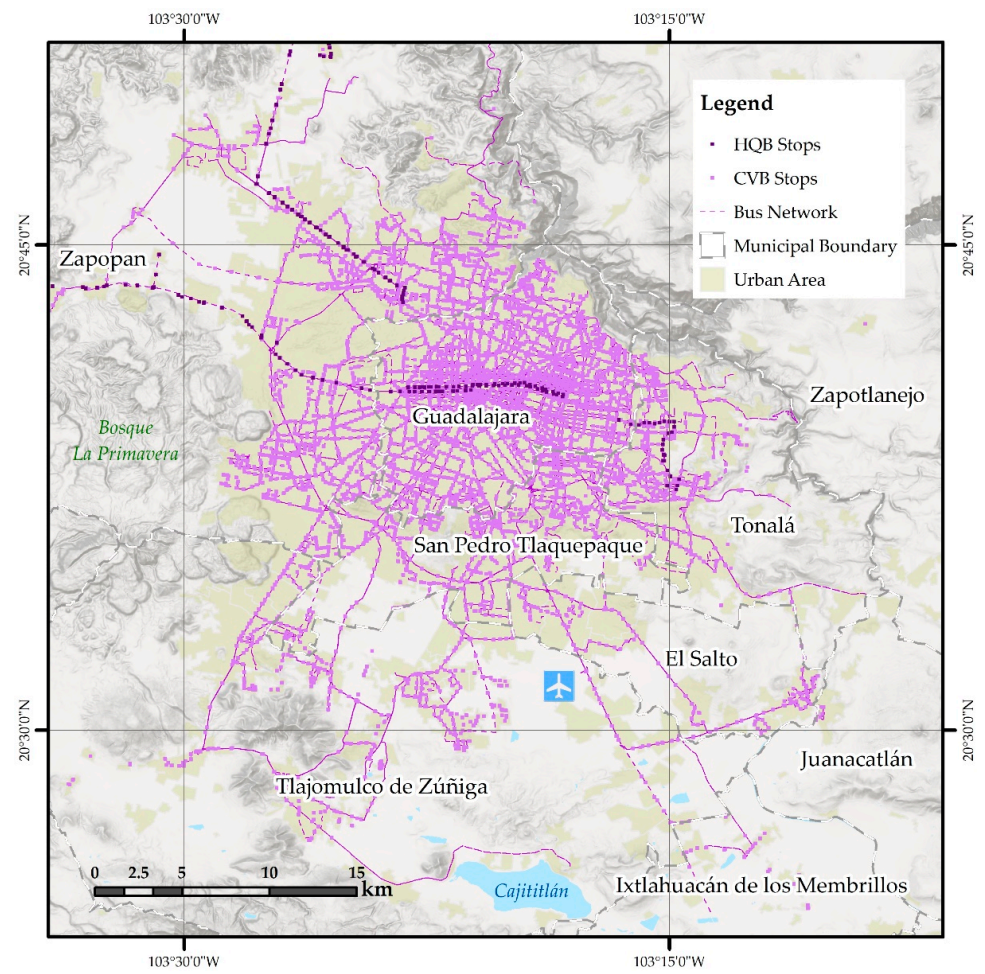

Figure 3. High-quality and conventional bus network in the Guadalajara Metropolitan Area (GMA). Source: authors, based on [78-83]. 


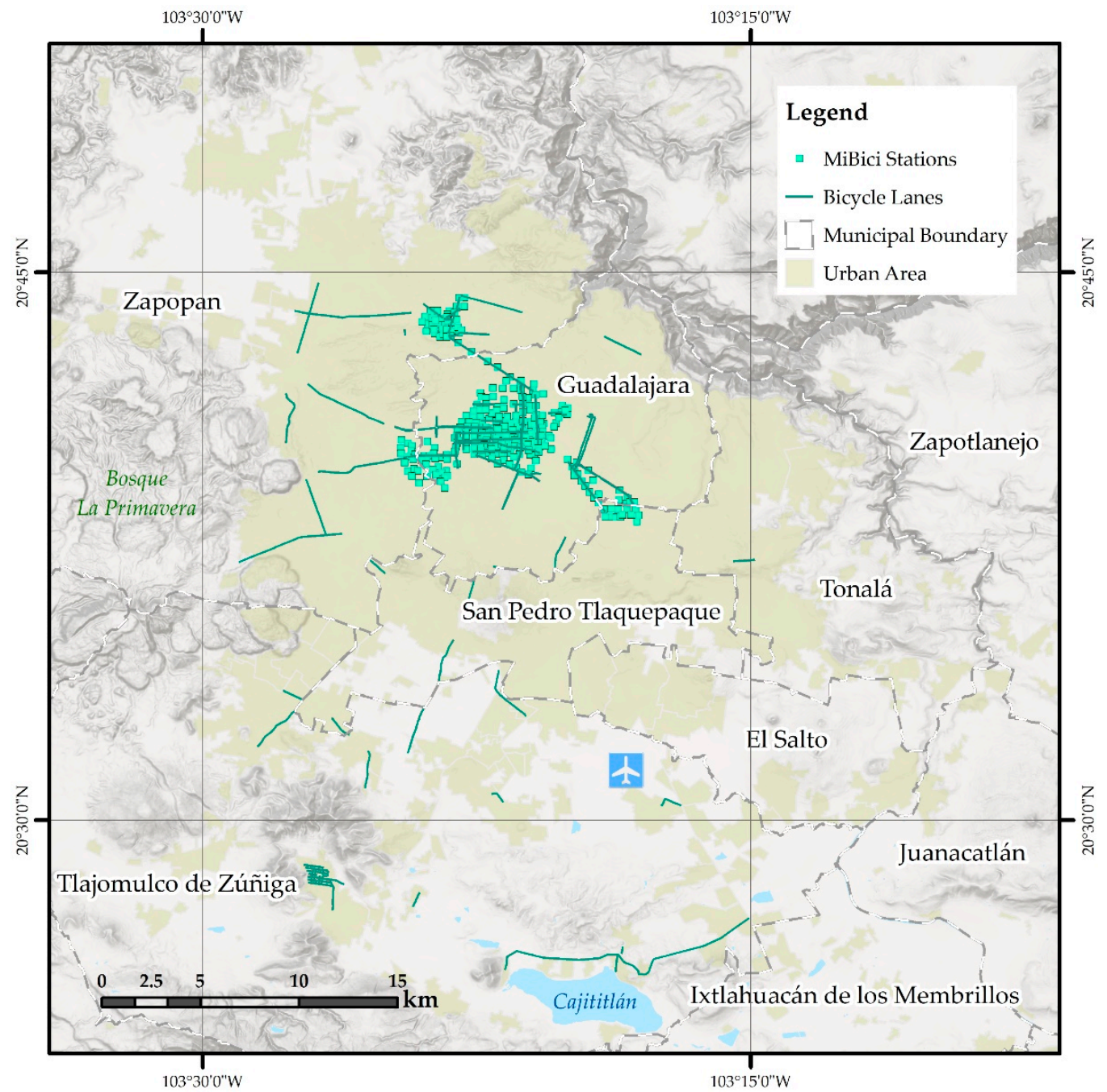

Figure 4. Bicycle system network in the Guadalajara Metropolitan Area (GMA). Source: authors, based on $[78-81,84]$.

In contrast with the students' transport modal split in North American universities [71], students in other regions have to rely on public transport or bicycles for their commute to universities [72]. Few modal split studies of university students in the GMA were found. In accordance with the Jalisco Government [85], 20.5\% of PT users in the GMA are students, but only $8.9 \%$ use PT for school commuting there. Most students walk between 1 and $15 \mathrm{~min}$ to reach their destination. Many students use their bicycles to complement their trips. Half of the students suggested improvements to schedules and frequency. García-Morales [73] studied a sample of three universities with respect to their modal split. The author stated that the modal split varies from one university to another, depending mainly on the accessibility to public transport and bicycle lanes in the vicinity of the facility, as well as on the type of administration, i.e., a public or private organisation.

There are different sources regarding university statistics. According to the National Institute of Statistics and Geography (INEGI) [86], there are 274 UFs in the GMA (see Figure 5). Only 26\% of them are publicly financed, even though public and private universities serve 163,678 and 86,738 students, respectively [87]. Both public and private universities provide services to students with financial difficulties, and most of the private universities have scholarship programmes for underprivileged students, e.g., ITESO (Technological and Higher Studies Institute of the West from its initials in Spanish) where almost half of the students receive financial aid. As shown in Figure 5, though the UFs are distributed in the central municipalities of the GMA, there is a concentration of public UFs in the central area, and private ones are located mainly in the 
municipalities of Guadalajara and Zapopan. The mid-south of the city is served by only a few public UFs, and the south, east and north of the GMA have few UFs.

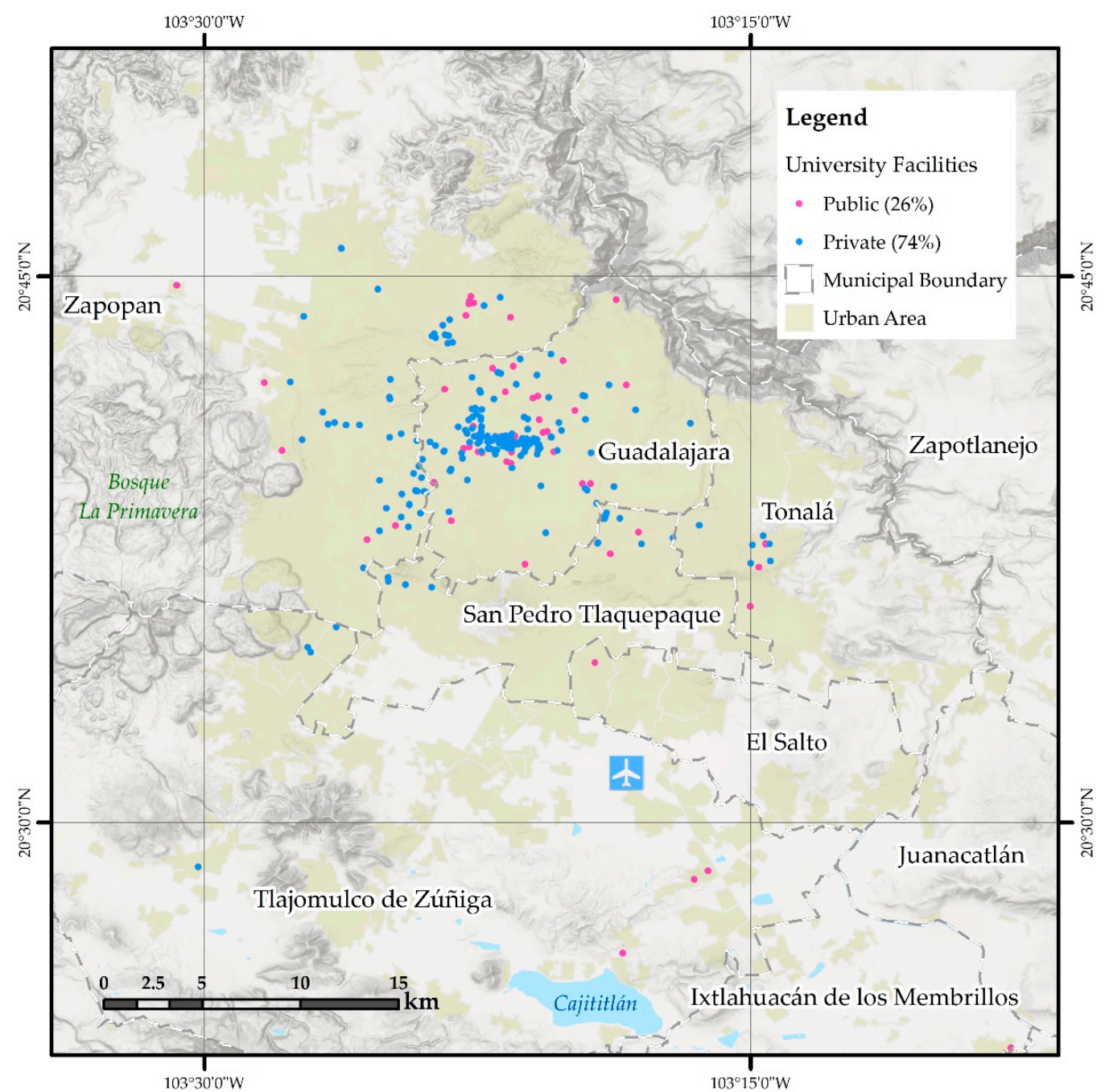

Figure 5. University facilities (UFs) in the Guadalajara Metropolitan Area (GMA). Source: authors, based on [78-81,86].

\subsection{Methodology}

Transport-related (in)equity is usually measured by means of accessibility [3]. Several methods of accessibility assessment were identified in the literature. Most of the authors refer to four approaches, i.e., proximity-based [5,42], also referred to as cumulative-based [34,88]; gravity-based; user-based; and space-time approaches [2]. In addition, Sun et al. [72] refer to "competition-based" assessment at transport nodes. For further discussion of approaches to accessibility measurement, readers are referred to, among others, these authors [9,24,25,68,88-94].

In this study, the nodes, routes, and bicycle lanes were counted as STMs. The ASTUI was calculated by the proximity and competition-based methods. These methods not only measure the total number of transport nodes available in an area within a desirable walking or cycling time [4,5,42], but also estimate the intensity of opportunities or their attractiveness [15]. The more routes there are at a stop, the more attractive it is. Thus, the ASTUI was assessed by calculating the number of sustainable transport nodes, as well as the number of routes or bicycle lanes available in the area of influence of each UF [5,42].

Figure 6 illustrates the conceptual model of the ASTUI. First, the service areas were calculated from the 274 UFs through the street network, which is a better predictor of human behavior than the use of Euclidian distance alone [95]. Then, the accumulation of nodes 
and routes for each mode and service area was spatially joined through a ModelBuilder ${ }^{\circledR}$ model within a Geographic Information System. Next, these variables were examined in a Principal Component Analysis (PCA), from which principal components were proposed, interpreted and selected. This method is used by the National Council for the Evaluation of Social Development Policy [96]. Finally, the ASTUIs were calculated by means of weighted variables from the PCA.

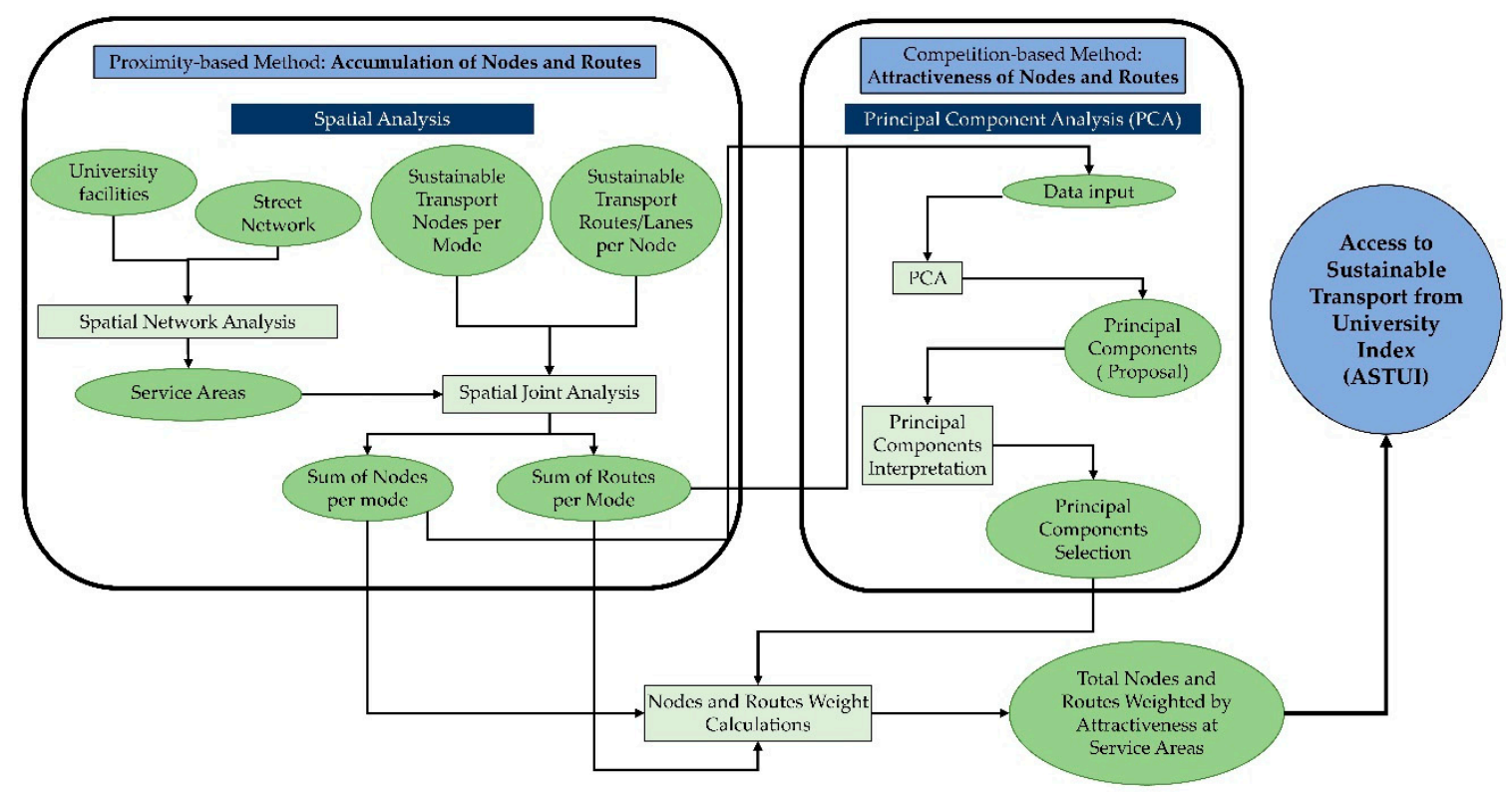

Figure 6. Access to Sustainable Transport from University Index (ASTUI) Conceptual Model. Source: authors.

The data required for the ASTUI calculation were the street network, the UFs, and the STM infrastructures. Table 1 lists the data used, and the Open Data produced by the government and crowdsourcing. The latter are continually verified by volunteers and improved by peer reviewers. The software used to calculate the ASTUIs was a Geographic Information System (GIS), which is well-recognised as an effective modelling technique to explore accessibility and network distances $[3,95,97]$, particularly the Network Analyst module of ArcMap Esri ${ }^{\circledR}$. StatGraphics ${ }^{\circledR}$ software was employed for the Principal Component Analysis and the cluster analysis. First, the service areas and the number of STM infrastructures were computed by means of Network Analysis. Then, the weightings of variables were computed with StatGraphics ${ }^{\circledR}$. Finally, the inequities were analysed, through clusters.

Table 1. Data sources.

\begin{tabular}{cc}
\hline Data. & Source \\
\hline Street Network & OpenStreetMap, October 2020 [98] \\
University Facilities & National Statistical Directory of Economic Units [86] \\
Light Rail System (SITEUR from its initials in \\
Mass Transport* and High-quality Buses & Spanish) [99-101] \\
Conventional Buses & Metropolitan Planning Institute [83] \\
Bicycle-sharing Stations and Lanes & Metropolitan Planning Institute [84] \\
\hline
\end{tabular}

* Mass Transport data included lines, stations, stops, frequency and vehicle capacity.

The calculation of the ASTUIs required the specification of the time threshold that the students are willing to walk or cycle, and the attractiveness of each node and route. Despite the sensitivity and importance of this criterion, there is a lack of consensus on the distance that people are willing to walk to reach public transport in a complex context such as the GMA [18]. To the authors' best knowledge, there is no standard of accessibility that 
is broadly accepted and used in urban and transport planning. Since the Transit Oriented Development (TOD) paradigm has already been applied in some areas of the city [102], this study used the time threshold that was defined most often by the TOD and already applied in other regions [42]. As shown in Table 2, the ASTUIs included the fulfilment of the TOD standard for the distance from universities to the STMs, i.e., fifteen minutes walking for mass transport, such as LRT and BRT; five minutes walking for high-quality and conventional buses; and two minutes cycling for MiBici stations and cycle lanes.

Table 2. Maximum time thresholds by mode of transport. Source: authors, adapted from [18,42].

\begin{tabular}{ccc}
\hline $\begin{array}{c}\text { Sustainable Transport } \\
\text { Mode }\end{array}$ & $\begin{array}{c}\text { Sustainable Transport Mode } \\
\text { Infrastructure (STM) }\end{array}$ & $\begin{array}{c}\text { Walking or Cycling Time Threshold } \\
\text { (Minutes) }\end{array}$ \\
\hline LRT * $^{*}$ & Station & 15 \\
BRT $^{*}$ & Station & 15 \\
High-quality Bus $^{*}$ & Stop & 5 \\
Conventional Bus & Stops and Routes ** & 5 \\
Bicycle & Stations and Bicycle Lanes ** & 2 \\
\hline
\end{tabular}

* SITEUR: Tren Ligero, Macrobús and Sitren. ${ }^{* *}$ The conventional buses and the bicycle sharing stations are the only modes with more than one route/lane at the stations/stops.

Figure 7 illustrates the numerical model for the ASTUI calculation. It includes three particularities of the study area. First, given that people are willing to walk up to $5 \mathrm{~min}$ to reach buses, they would also walk this distance to reach a bicycle-sharing station to complete the journey by cycling. Therefore, the MiBici stations were counted within this service area. Second, bicycles are allowed on LRT and the high-quality buses, i.e., Sitren. Consequently, these two types of stations and stops were computed for the service area of 2 min cycling. This is not the case for BRT or conventional buses. Third, there is only one route at the LRT, BRT and Sitren stations. Thus, the routes for these modes were not counted, in order to avoid biases in the PCA. In contrast, there is usually more than one route at the conventional bus stops and more than one cycle lane at the MiBici stations. Thus, the routes and cycle lanes were counted for both modes. Based on these particularities, the spatial analysis for the service areas and the number of STMs were computed by means of Network Analyst, with the ModelBuilder from Esri ${ }^{\circledR}$.

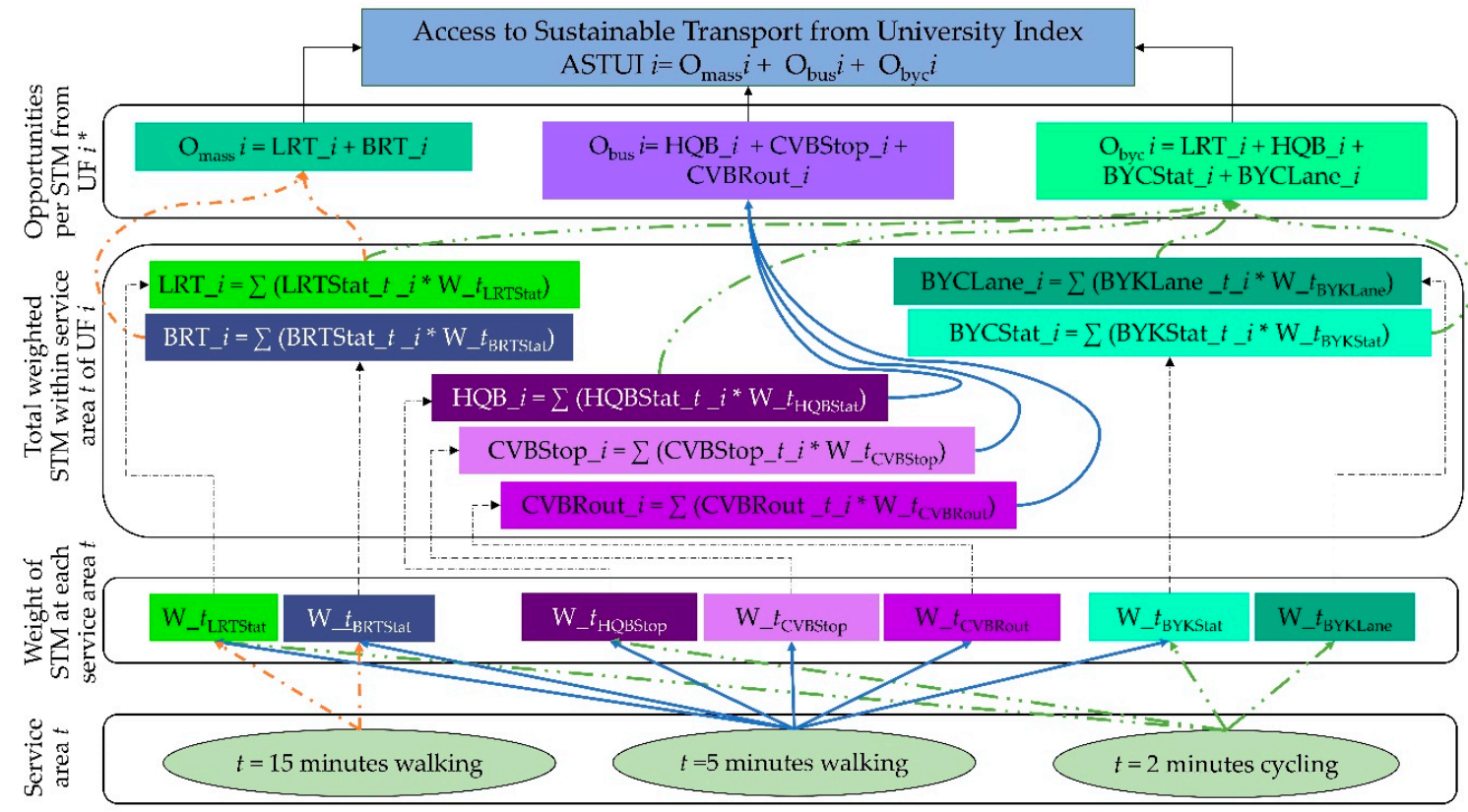

Figure 7. Access to Sustainable Transport from University Index (ASTUI) Numerical Model. Source: the authors. 
The Principal Component Analysis (PCA) describes the correlations between the STM infrastructure variables referred to in Table 3 by creating new components that propose the weights of the original variables for the 274 UFs [91,96,103-106]. The purpose of the PCA is to obtain a small number of linear combinations of the 12 variables that account for most of the variability in the data. Each component can be interpreted as one part of the accessibility phenomenon. A negative value means that this variable negatively affects accessibility. Three components were retained, since their eigenvalues were greater than or equal to 1.0 , as shown in Table 4 . Together, they account for $72.4925 \%$ of the variability in the original data.

Table 3. Input variables of the service area and the Principal Component Analysis. Source: the authors.

\begin{tabular}{|c|c|c|c|c|}
\hline $\begin{array}{l}\text { STM id } \\
{\left[\mathrm{ST}_{\mathrm{id}}\right]}\end{array}$ & $\begin{array}{l}\text { Sustainable Transport Mode } \\
\text { Infrastructures }\end{array}$ & $\begin{array}{c}t=15 \\
\text { [Walking Minutes] }\end{array}$ & $\begin{array}{c}t=5 \\
\text { [Walking Minutes] }\end{array}$ & $\begin{array}{c}t=2 \\
\text { [Cycling Minutes] }\end{array}$ \\
\hline A & \multirow{3}{*}{$\begin{array}{l}\text { Number of LRT Stations in } \\
\text { Service Area } t \text { (Tren Ligero) }\end{array}$} & F15_LRT & \multirow{3}{*}{ F5_LRT } & \multirow{5}{*}{ B2_LRT } \\
\hline $\mathrm{B}$ & & & & \\
\hline $\mathrm{C}$ & & & & \\
\hline $\mathrm{D}$ & Number of BRT Stations in & \multirow[t]{2}{*}{ F15_BRT } & \multirow[b]{2}{*}{ F5_BRT } & \\
\hline $\mathrm{E}$ & Service Area $t$ (Macrobús) & & & \\
\hline $\mathrm{F}$ & Number of High-quality Bus & \multirow{2}{*}{\multicolumn{2}{|c|}{ F5_HQB }} & \\
\hline G & Stops in Service Area $t$ (Sitren) & & & B2_HQB \\
\hline $\mathrm{H}$ & $\begin{array}{c}\text { Number of Conventional Bus } \\
\text { Stops in Service Area } t\end{array}$ & \multicolumn{2}{|r|}{ F5_CNB } & \\
\hline I & $\begin{array}{c}\text { Number of Conventional Bus } \\
\text { Routes in Service Area } t\end{array}$ & \multicolumn{2}{|r|}{ F5_CNB } & \\
\hline $\mathrm{J}$ & Number of MiBici Stations in & \multirow{2}{*}{\multicolumn{2}{|c|}{ F5_BYK }} & \multirow[b]{2}{*}{$\mathrm{B} 2 \_\mathrm{BYK}_{\mathrm{s}}$} \\
\hline $\mathrm{K}$ & Service Area $t$ & & & \\
\hline $\mathrm{L}$ & $\begin{array}{c}\text { Number of Bicycle Lanes in } \\
\text { Service Area } t\end{array}$ & & & B2_BYK 1 \\
\hline
\end{tabular}

Table 4. Principal Component Analysis Components. Source: the authors.

\begin{tabular}{cccc}
\hline $\begin{array}{c}\text { Component. } \\
\text { Number }\end{array}$ & Eigenvalue & $\begin{array}{c}\text { Variance } \\
{[\%]}\end{array}$ & $\begin{array}{c}\text { Cumulative } \\
\text { Variance } \\
{[\%]}\end{array}$ \\
\hline 1 & 5.19051 & 43.254 & 43.254 \\
2 & 2.21364 & 18.447 & 61.701 \\
3 & 1.29495 & 10.791 & 72.493 \\
4 & 0.966089 & 8.051 & 80.543 \\
5 & 0.7064 & 5.887 & 86.430 \\
6 & 0.404834 & 3.374 & 89.804 \\
7 & 0.319993 & 2.667 & 92.470 \\
8 & 0.288061 & 2.401 & 94.871 \\
9 & 0.240288 & 2.002 & 96.873 \\
10 & 0.218669 & 1.822 & 98.695 \\
11 & 0.0839818 & 0.700 & 99.395 \\
12 & 0.072579 & 0.605 & 100.000 \\
\hline
\end{tabular}

The factorability tests provide an indication of whether or not it is likely to be worthwhile to attempt to extract factors from a set of variables. The Kaiser-Meyer-Olkin (KMO) Measure of Sampling Adequacy statistic delivers an indication of how much common variance is present. For the factorisation to be worthwhile, the KMO should normally be at least 0.6 . Since the $\mathrm{KMO}=0.786828$, factorisation is likely to provide meaningful information about any underlying factors.

The three components that were retained were interpreted by the variable weights shown in Table 5. They represent the relationship between the original variables and 
the principal components. Component 1, named the 'Multimodal Transport System', represents all of the modes of transport retained in the study with less importance than the BRT, as the values of its variables are smaller than the others. Component 2, named the 'Mass Transport System', favours mass modes of transport, i.e., the Tren Ligero and the Macrobús, and gives negative or very low values to modes linked to bicycles and buses, both Sitren and conventional. Component 3, named the 'Bus Rapid Transit' component, prioritises this mode, and thus it complements Component 1.

Table 5. Component Weights. Source: the authors.

\begin{tabular}{ccccc}
\hline $\begin{array}{c}\text { Component Weight ID } \\
\text { [id] }\end{array}$ & Variable & Component_1 & Component_2 & Component_3 \\
\hline W $_{\mathrm{A}}$ & F15_LRT & 0.318819 & 0.296047 & -0.197854 \\
W $_{\mathrm{B}}$ & F5_LRT & 0.225533 & 0.302996 & -0.383931 \\
W $_{\mathrm{C}}$ & B2_LRT & 0.288487 & 0.224921 & -0.386717 \\
W $_{\mathrm{D}}$ & F15_BRT & 0.135682 & 0.443007 & 0.488484 \\
$\mathrm{~W}_{\mathrm{E}}$ & F5_BRT & 0.047106 & 0.311531 & 0.576449 \\
$\mathrm{~W}_{\mathrm{F}}$ & F5_HQB & 0.255624 & -0.380555 & 0.174918 \\
$\mathrm{~W}_{\mathrm{G}}$ & B2_HQB & 0.283082 & -0.378544 & 0.155742 \\
$\mathrm{~W}_{\mathrm{H}}$ & F5_CNB & 0.352379 & 0.0976065 & 0.0679395 \\
$\mathrm{~W}_{\mathrm{I}}$ & F5_CNB & 0.329129 & 0.225656 & 0.00105742 \\
$\mathrm{~W}_{\mathrm{J}}$ & F5_BYK & 0.361178 & -0.140043 & 0.106823 \\
$\mathrm{~W}_{\mathrm{K}}$ & B2_BYK $_{\mathrm{S}}$ & 0.378923 & -0.207403 & 0.116437 \\
$\mathrm{~W}_{\mathrm{L}}$ & B2_BYK & 0.3027 & -0.255853 & -0.0924796 \\
\hline
\end{tabular}

Equation (1) shows an example of the first principal component, where the values of the variables in the equation must be standardised by subtracting their means and dividing by their standard deviations.

The three components were calculated by means of Equation (2).

$$
\begin{gathered}
\text { Component } 1=0.318819 * \text { F15_LRTStat }+0.225533 * \text { F5_LRTStat }+0.288487 * \text { B2_LRTStat }+0.135682 * \\
\text { F15_BRTStat }+0.047106 * \text { F5_BRTStat }+0.255624 * \text { F5_HQBStop }+0.283082 * \text { B2_HQBStop }+0.352379 * \\
\text { F5_CVBStop }+0.329129 * \text { F5_CVBRout }+0.361178 * \text { F5_BYKStat }+0.378923 * \text { B2_BYKStat }+0.3027 * \\
\text { B2_BYKLane }
\end{gathered}
$$

$$
\begin{gathered}
\text { Component_n= } \mathrm{A} * \mathrm{~W}_{\mathrm{A}} n+\mathrm{B} * \mathrm{~W}_{\mathrm{B}} n+\mathrm{C} * \mathrm{~W}_{\mathrm{C}} n+\mathrm{D} * \mathrm{~W}_{\mathrm{D}} n+\mathrm{E} * \mathrm{~W}_{\mathrm{E}} n+\mathrm{F}^{*} \mathrm{~W}_{\mathrm{F}} n+\mathrm{G}^{*} \mathrm{~W}_{\mathrm{G}} n+\mathrm{H}^{*} \mathrm{~W}_{\mathrm{H}} n+\mathrm{I} * \\
\mathrm{~W}_{\mathrm{I}} n+\mathrm{J}^{*} \mathrm{~W}_{\mathrm{J}} n+\mathrm{K}^{*} \mathrm{~W}_{\mathrm{K}} n+\mathrm{L}^{*} \mathrm{~W}_{\mathrm{L}} n
\end{gathered}
$$

where $n=$ the number of components from Table 4, i.e., $\{1,2,3\}$.

A to $\mathrm{K}=$ the variables listed in Table 2, standardised by subtracting their means and dividing by their standard deviations.

$\mathrm{W}_{\mathrm{A}} n$ to $\mathrm{W}_{\mathrm{L}} n=$ the weight of each variable A-L at component $n$, as shown in Table 4 .

An average of the three components was retained for the ASTUI calculation at UF $i$, as shown in Equation (3).

ASTUI $i=\left[\left(\right.\right.$ Eigenvalue_1 ${ }^{*}$ Component_1 $)+\left(\right.$ Eigenvalue_2 ${ }^{*}$ Component_2 $)+($ Eigenvalue_3 * Component_3)]/[Eigenvalue_1 + Eigenvalue_2 + Eigenvalue_3]

Recent literature refers to statistics for the measurement ofthe (in)equity of spatial accessibility $[2,34,72]$, particularly cluster analyses [24,96]. These computations served to identify homogeneous areas, reducing the number of the 274 UFs by the classification of 5 strata, thus simplifying the data interpretation of the (in)equity of the accessibility to STMs from UFs.

The clustering method was Ward's, with the squared Euclidean distance metric and non-standardised observations. According to the StatGraphics ${ }^{\circledR}$ report, the procedure began with each observation in a separate group. It then combined the two observations that were closest together to form a new group. After recomputing the distance between the groups, the two groups that were now closest together were combined. This process was 
repeated until only 5 groups remained. The computations served to identify homogeneous areas, reducing the number of the 274 UFs by the classification of the limited number of strata shown in Table 6 . Then, the vertical equity of the spatial accessibility was calculated by statistical comparisons of the ASTUIs at private/public universities.

Table 6. Cluster analysis results. Source: the authors.

\begin{tabular}{ccccc}
\hline Strata & Centroid of ASTUI & Cluster & Members & Percent [\%] \\
\hline Very Low & -1.26353 & 2 & 105 & 38.32 \\
Low & -0.349644 & 4 & 62 & 22.63 \\
Medium & 0.686179 & 3 & 60 & 21.90 \\
High & 1.54135 & 1 & 25 & 9.12 \\
Very High & 3.39289 & 5 & 22 & 8.03 \\
\hline
\end{tabular}

\section{Results and Discussion}

According to Litman [5] and recent literature [2,47,107], transport equity can be horizontal or vertical. Horizontal equity assumes that everyone has the same right to access basic goods, or that the group has equal abilities and needs. Since the accessibility of UFs is recognised as a basic good [108], horizontal equity means that the STMs do not favour any UF. Every student should have equitable access to sustainable transport means from their UF in the current era of the Sustainable Development Goals.

Figure 8 shows the ASTUI spatial pattern for the analysis of horizontal (in)equity. Even though the public UFs seem to be 'near' SITEUR, this study ascertained that the vicinity is not within the standards recommended in the ASTUI. The figure also shows that almost half of the UFs have Low and Very Low accessibility, while less than $10 \%$ of the UFs meet the standard of the Transport Oriented Development paradigm. This is empirical evidence of the transport-related social exclusion of university students, who have traditionally been under-represented in public transport policies.

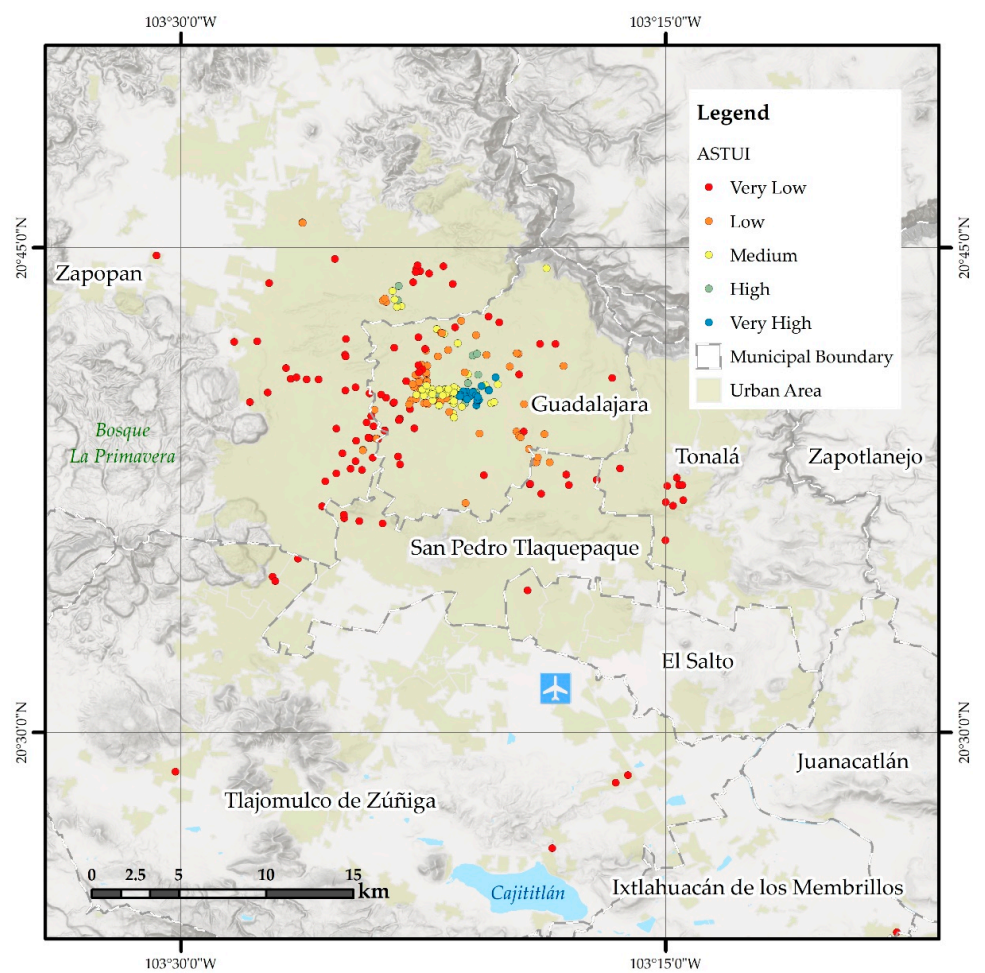

Figure 8. Access to Sustainable Transport from University Index (ASTUI) in the Guadalajara Metropolitan Area (GMA). Source: the authors, based on [78-81]. 
Vertical equity refers to social and/or income class [5,91]. It suggests that the distribution of STMs should favour a specific group of students. The ASTUIs were compared across the public and private UFs. An egalitarian accessibility policy should ensure that the location of the STMs does not negatively impact students attending universities with public funds. Other factors, such as the number of students and their gender, are relevant to transport equity analyses. However, only funding sources were financial factors were computed in this project, given the data availability.

According to the calculation of the ASTUIs and their classification by clusters, most of the university infrastructure has low and very low ASTUI values, i.e., $62.0 \%$ and $42.3 \%$ for public and private infrastructure, respectively. Nevertheless, as shown in Figure 9, there is no spatial pattern of inequity between public and private infrastructure. Although more private infrastructure is observed in the three most disadvantaged strata, the relative difference between them is small, i.e., 5\%, 8\%, and 3\% for 'Very Low', 'Low' and 'Medium', respectively. There are 14 percentage points of difference in the 'High' stratum that favours public infrastructure. In the 'Very High' stratum, private infrastructure is favoured over the public infrastructure by 9 percentage points.

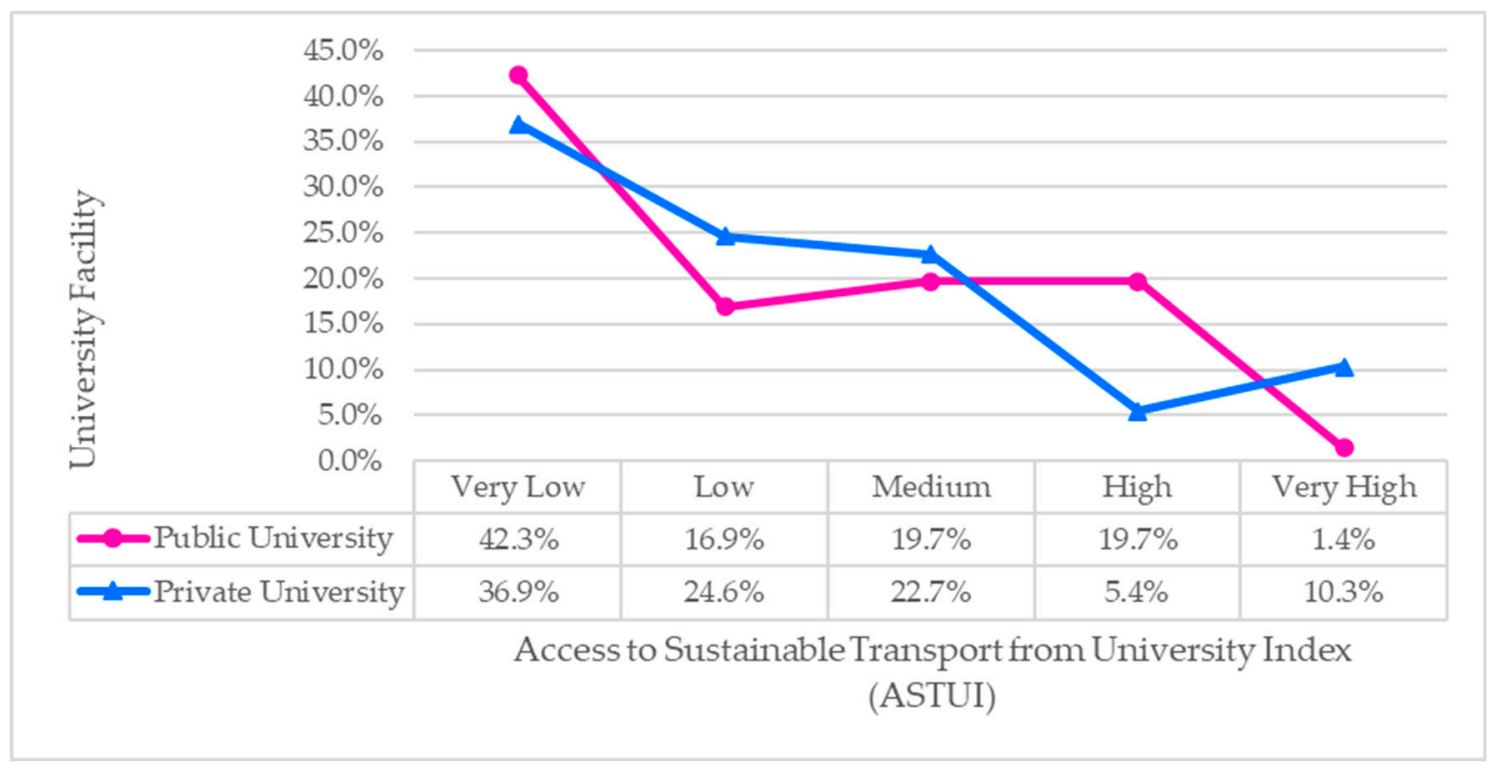

Figure 9. Inequity distribution of the Access to Sustainable Transport from University Index (ASTUI) in the Guadalajara Metropolitan Area (GMA). Source: the authors.

According to Guthrie et al. [4], the results highlight that university students in the GMA are under-represented in transport planning. In spite of the investments in the SITEUR and the governmental subsidies for students to use public transport [77] and MiBici, this study revealed that transport-related social exclusion persists within this disadvantaged group. Several reasons were identified that discourage the use of sustainable transport by university students. First, despite the extensive area served by conventional buses, they offer a low-quality service [109]. Second, most of the UFs are further away than a 2-min bicycle ride from the MiBici stations and bicycle lanes. Third, notwithstanding the high-quality service offered by SITEUR [38], the LRT, BRT and Sitren cover only a small proportion of the GMA.

The public transport system is considered to be a promoter of social inclusion. This is more relevant in areas that are traditionally characterised by high levels of structural inequalities, such as the GMA. This research identified low access levels for the university student population, which means that the study detected transport-related social exclusion [110]. The authors propose general actions to enhance the equity of opportunities not just for university students but also for other groups with transport-related disadvantages. 
Guaranteeing the quality of the conventional buses and building a safe, interconnected, and larger bicycle lane network will reduce the transport disadvantages of university students. The researchers also propose the incorporation of university students and authorities into the decision-making process for transport planning and policies, in order to reduce the accessibility disparities experienced by this under-represented, but socially relevant [111], community.

\section{Conclusions}

According to this research, the promotion of sustainable transport modes in the vicinity of UFs is not supported by the GMA's public transport policies, nor is the intention to modify the future travel behaviour of current students. Indeed, the GMA is very far from the paradigm of a more equitable and livable city when it comes to sustainable mobility in the vicinity of UF. As expected, university students in the GMA suffer transport-related social exclusion when they access LRT, BRT, buses, and bicycles. It affects all students, since the ASTUI is similar in the public and private UI, except for the average values of the index, where the public UI is favoured.

The analysis does not fully confirm the inequity between private and public UFs, and a deeper analysis must be carried out in future research, since this study has some limitations. First, the number of students at each UF was not available in Open Data sources, and thus the analysis did not distinguish according to the 'size' of each UF. Second, the results may be significantly different, as the service areas vary. Third, the ASTUIs did not include walking or travel impedances, such as transport fees, topography, security, or other urban quality indicators. Fourth, (in)equity is difficult to measure due to the subjective (individual) nature of accessibility. Therefore, the results of this research are plausible, but not yet completely established.

Although this paper represents a significant advancement of the prior work in the GMA, there is still room for improvement. Future tasks that could enhance this research include:

- Considering the topography and urban environment as elements of effective mobility for the measurement of hindrances affecting the walking time to the stops/stations.

- Computing a sensitivity analysis for different service areas.

- Including the BRT line currently under construction. According to Jalisco [112], this line will serve more than 49,000 students.

- Considering income, gender, physical ability, or other vulnerabilities in the student population.

- Accounting for the impact of transport fees in the model.

- Including data from smartcards and General Transit Feed Specifications as soon as they are available.

- Transferring the proposed methodology to the calculation of indices for other basic goods, such as health, cultural, or basic educational infrastructure.

It is necessary to shift the mobility paradigm, taking advantage of the adaptation inertia in the post-COVID era. This study proposed a simple and powerful approach to improve the practice of transport planning and policies. It is easy to understand, interpret and replicate for policy makers in metropolitan areas similar to the GMA who seek to reduce inequality in the form of transport-related social exclusion.

Author Contributions: Conceptualization, H.d.A.-M. and G.O.-C.; Data curation, H.d.A.-M. and G.O.-C.; Formal analysis, H.d.A.-M. and G.O.-C.; Funding acquisition, H.d.A.-M. and A.L.G.; Investigation G.O.-C.; Methodology, H.d.A.-M. and G.O.-C.; Project administration, G.O.-C.; Resources, H.d.A.-M. and A.L.G.; Supervision, H.d.A.-M. and A.L.G.; Validation, H.d.A.-M. A.L.G. and G.O.-C.; Visualization, H.d.A.-M. and G.O.-C.; Writing-original draft, G.O.-C.; Writing-review and editing, H.d.A.-M. and A.L.G. All authors have read and agreed to the published version of the manuscript.

Funding: This research was partially supported by CONACyT (México), the Alliance for Training and Research in Infrastructure for Development of Mexico, A.C. (FIIDEM). This research project also ben- 
efited from ITESO, the Jesuit University of Guadalajara, for Research Support Program scholarships for Ivana Georgina Kroepfly Cota and the SUPA program for Gabriela Ochoa-Covarrubias.

Institutional Review Board Statement: Not applicable.

Informed Consent Statement: Not applicable

Data Availability Statement: The data presented in this study are available on request from the corresponding author. The data are not publicly available due to repository administrative procedures. They will be published as soon as possible.

Acknowledgments: We gratefully thank Ivana Georgina Kroepfly Cota, Juan Pablo Jiménez González and Orlando Andrade Barraza for the provision of the bicycle and conventional bus data. We also acknowledge Associate Professor Emilio Molero Melgarejo (University of Granada) and the reviewers for their contribution of professional guidance and suggestions.

Conflicts of Interest: The authors declare no conflict of interest.

\section{References}

1. Astakhova, K.V.; Korobeev, A.I.; Prokhorova, V.V.; Kolupaev, A.A.; Vorotnoy, M.V.; Kucheryavaya, E.R. The Role of Education in Economic and Social Development of the Country. Int. Rev. Manag. Mark. 2016, 6, 53-58.

2. Kelobonye, K.; McCarney, G.; Xia, J.; Swapan, M.S.H.; Mao, F.; Zhou, H. Relative Accessibility Analysis for Key Land Uses: A Spatial Equity Perspective. J. Transp. Geogr. 2019, 75, 82-93. [CrossRef]

3. Xia, J.; Nesbitt, J.; Daley, R.; Najnin, A.; Litman, T.; Tiwari, S.P. A Multi-Dimensional View of Transport-Related Social Exclusion: A Comparative Study of Greater Perth and Sydney. Transp. Res. Part A Policy Pract. 2016, 94, 205-221. [CrossRef]

4. Guthrie, A.; Fan, Y.; Van Dort, L.; Baas, G. Advancing Transportation Equity: Research and Practice; Minnesota Department of Transportation: Saint Paul, MN, USA, 2019; p. 81.

5. Litman, T. Evaluating Transportation Equity. World Transp. Policy Pract. 2002, 8, 50-65.

6. Wachs, M.; Kumagai, T.G. Physical Accessibility as a Social Indicator. Socio-Econ. Plan. Sci. 1973, 7, 437-456. [CrossRef]

7. Kenyon, S. Tackling Transport-Related Social Exclusion: Considering Virtual Access to Opportunities, Services and Social Networks. New Technol. Hum. Serv. 2002, 14, 10-22.

8. Kenyon, S.; Lyons, G.; Rafferty, J. Transport and Social Exclusion: Investigating the Possibility of Promoting Inclusion through Virtual Mobility. J. Transp. Geogr. 2002, 10, 207-219. [CrossRef]

9. Litman, T. Evaluating Accessibility for Transportation Planning. Measuring People's Ability To Reach Desired Goods and Activities. Vic. Transp. Policy Inst. 2012, 50. Available online: http:/ / www.vtpi.org (accessed on 3 November 2020).

10. Lucas, K. A New Evolution for Transport-Related Social Exclusion Research? J. Transp. Geogr. 2019, 81, 102529. [CrossRef]

11. Social Exclusion Unit. Making the Connections: Final Report on Transport and Social Exclusion; Office of the Deputy Prime Minister: London, UK, 2003; p. 147.

12. Bertolini, L.; le Clercq, F.; Kapoen, L. Sustainable Accessibility: A Conceptual Framework to Integrate Transport and Land Use Plan-Making. Two Test-Applications in the Netherlands and a Reflection on the Way Forward. Transp. Policy 2005, 12, 207-220. [CrossRef]

13. Cervero, R. Paradigm Shift: From Automobility to Accessibility Planning. Urban Futures (Canberra) 1997, 22, 9-20.

14. Guthrie, A. Can Transit-Oriented Development Enhance Social Equity: Current State and Active Promotion of Equitable Transit-Oriented Development; University of Minnesota: Minneapolis, MN, USA, 2018.

15. Handy, S. Is Accessibility an Idea Whose Time Has Finally Come? Transp. Res. Part D Transp. Environ. 2020, 83, 102319. [CrossRef]

16. Kamruzzaman, M.; Yigitcanlar, T.; Yang, J.; Mohamed, M.A. Measures of Transport-Related Social Exclusion: A Critical Review of the Literature. Sustainability 2016, 8, 696. [CrossRef]

17. Schwanen, T.; Lucas, K.; Akyelken, N.; Cisternas Solsona, D.; Carrasco, J.-A.; Neutens, T. Rethinking the Links between Social Exclusion and Transport Disadvantage through the Lens of Social Capital. Transp. Res. Part A Policy Pract. 2015, 74, 123-135. [CrossRef]

18. Talavera-Garcia, R.; Valenzuela-Montes, L.M. Conceptual Analysis of Walking Distance to Transit: Towards a More Integrative Approach. Ace-Arch. City Environ. 2018, 13, 183-204. [CrossRef]

19. Cheng, J.; Yan, R.; Gao, Y. Exploring Spatial Heterogeneity in Accessibility and Transit Mode Choice. Transp. Res. Part D Transp. Environ. 2020, 87, 102521. [CrossRef]

20. Ermagun, A.; Tilahun, N. Equity of Transit Accessibility across Chicago. Transp. Res. Part D Transp. Environ. 2020, 86, 102461. [CrossRef]

21. Gutiérrez-Puebla, J.; García-Palomares, J.C.; Alventosa, C.; Redondo, J.C.; Paniagua, E. Accesibilidad peatonal a la red sanitaria de asistencia primaria en Madrid. An. De Geogr. De La Univ. Complut. 2002, 1, 269-280.

22. Guzman, L.A.; Oviedo, D.; Rivera, C. Assessing Equity in Transport Accessibility to Work and Study: The Bogotá Region. J. Transp. Geogr. 2017, 58, 236-246. [CrossRef] 
23. Lamíquiz Daudén, F.J. Implicaciones de la Accesibilidad Configuracional en la Movilidad Peatonal. El caso de Madrid. Ph.D. Thesis, Universidad Politécnica de Madrid, Madrid, Spain, 2011. Available online: http:/ / oa.upm.es/15031/ (accessed on 10 October 2020).

24. Pritchard, J.P.; Tomasiello, D.B.; Giannotti, M.; Geurs, K. Potential Impacts of Bike-and-Ride on Job Accessibility and Spatial Equity in São Paulo, Brazil. Transp. Res. Part A Policy Pract. 2019, 121, 386-400. [CrossRef]

25. Stępniak, M.; Pritchard, J.P.; Geurs, K.T.; Goliszek, S. The Impact of Temporal Resolution on Public Transport Accessibility Measurement: Review and Case Study in Poland. J. Transp. Geogr. 2019, 75, 8-24. [CrossRef]

26. Bocarejo S, J.P.; Oviedo H, D.R. Transport Accessibility and Social Inequities: A Tool for Identification of Mobility Needs and Evaluation of Transport Investments. J. Transp. Geogr. 2012, 24, 142-154. [CrossRef]

27. Calonge Reillo, F.; Aceves Arce, R.H. Viajando por sectores no centrales del área metropolitana de Guadalajara, México. La escasez de recursos y de alternativas de transporte como condicionantes de la exclusión social. Sociológica 2019, 34, 137-168. [CrossRef]

28. Esquivel-Cuevas, M.; Hernández-Mercado, O.A.; Garnica-Monroy, R. Pedestrian Accessibility Model. Pedestrian accessibility index at neighborhood scale. Bitácora Urbano Territ. 2013, 23, 21-30.

29. Grindlay, A.L.; Jaramillo, C.; Lizárraga, C. Spatial Relationships Between Mobility Opportunities and Constraints of Transport Disadvantages: The Case of Santiago De Cali, Colombia. In Urban Transport Xxiii; Ricci, S., Brebbia, C.A., Eds.; Wit Press: Southampton, UK, 2018; Volume 176, pp. 119-129. ISBN 978-1-78466-210-3.

30. Guzman, L.A.; Oviedo, D. Accessibility, Affordability and Equity: Assessing 'pro-Poor' Public Transport Subsidies in Bogotá. Transp. Policy 2018, 68, 37-51. [CrossRef]

31. Jaramillo, C.; Lizárraga, C.; Grindlay, A.L. Spatial Disparity in Transport Social Needs and Public Transport Provision in Santiago de Cali (Colombia). J. Transp. Geogr. 2012, 24, 340-357. [CrossRef]

32. Lizárraga, C. Metropolitan expansion and mobility: The case of Caracas. Eure 2012, 38, 99-125. [CrossRef]

33. Medina, S.; Patlán, M. Modelo de implementación de DOT en la Zona Metropolitana de Guadalajara; Secretaría de Desarrollo Agrario, Territorial y Urbano, Secretaría de Medio Ambiente y Recursos Naturales, ISAID e ITDP: Ciudad de, Mexico, 2016 ; p. 103.

34. Pereira, R.H.M. Future Accessibility Impacts of Transport Policy Scenarios: Equity and Sensitivity to Travel Time Thresholds for Bus Rapid Transit Expansion in Rio de Janeiro. J. Transp. Geogr. 2019, 74, 321-332. [CrossRef]

35. Montoya-Robledo, V.; Escovar-Alvarez, G. Domestic Workers' Commutes in Bogota: Transportation, Gender and Social Exclusion. Transp. Res. Pt. A-Policy Pract. 2020, 139, 400-411. [CrossRef]

36. Shirahige, M.; Correa, J. La desigualdad en el acceso al transporte público en el área metropolitana de Santiago: Análisis mediante la aplicación delmodelo PTAL en campamentos y villas de blocks. Rev. Cis 2015, 12, 55-89.

37. Terán-Hernández, M. Accesibilidad espacial de los servicios de prevención y control del cáncer-cervicouterino en San Luis Potosí I Investigaciones Geográficas. Investig. Geográficas 2017, 94. [CrossRef]

38. UN-Habitat; Jalisco, G. del E. de J. (Government of the S. of J. Guadalajara-Metropolitana. Prosperidad Urbana: Oportunidades y Propuestas. Guadalajara, 2017. Available online: https://onuhabitat.org.mx/index.php/guadalajara-metropolitana-prosperidadurbana-oportunidades-y-propuestas (accessed on 26 September 2019).

39. Vecchio, G.; Tiznado-Aitken, I.; Hurtubia, R. Transport and Equity in Latin America: A Critical Review of Socially Oriented Accessibility Assessments. Transp. Rev. 2020, 1-28. [CrossRef]

40. Cohen, T. Tools for Addressing Transport Inequality: A Novel Variant of Accessibility Measurement. J. Transp. Geogr. 2020, 88,102863 . [CrossRef]

41. Vuchic, V.R. Transportation for Livable Cities; Routledge: Abingdon, UK, 2017; ISBN 978-1-351-31814-3.

42. UEA, A. de E.U. de B. (Urban E.A., Spain) Guía metodológica para los sistemas de auditoría, certificación o acreditación de la calidad y sostenibilidad en el medio urbano; Centro de publicaciones, Secretaría General Técnica. Ministerio de Fomento, 2012; ISBN 978-84-498-0914-9. Available online: https:/ / www.mitma.gob.es/areas-de-actividad/arquitectura-vivienda-y-suelo/ urbanismo-y-politica-de-suelo/urbanismo-y-sostenibilidad-urbana / guia-metodologica-para-los-sistemas-de-auditoriacertificacion-o-acreditacion-de-la-calidad-y-sostenibilidad-en-el-medio-urbano (accessed on 20 December 2020).

43. Allen, J.; Farber, S. How Time-Use and Transportation Barriers Limit on-Campus Participation of University Students. Travel Behav. Soc. 2018, 13, 174-182. [CrossRef]

44. Jalisco, G. del E. de J. (Government of the S. of J. Apoyo al Transporte para Estudiantes. Available online: https:/ / programas.app. jalisco.gob.mx/programas/apoyo/Apoyo-al-transporte-para-estudiantes/663 (accessed on 26 October 2020).

45. Cattaneo, M.; Malighetti, P.; Morlotti, C.; Paleari, S. Students' Mobility Attitudes and Sustainable Transport Mode Choice. IJSHE 2018, 19, 942-962. [CrossRef]

46. Vecchio, G.; Porreca, R.; Jácome Rivera, D. Socio-Spatial Concerns in Urban Mobility Planning: Insights from Competing Policies in Quito. Sustainability 2020, 12, 2923. [CrossRef]

47. Oviedo, D.; Guzman, L.A. Revisiting Accessibility in a Context of Sustainable Transport: Capabilities and Inequalities in Bogotá. Sustainability 2020, 12, 4464. [CrossRef]

48. Macioszek, E.; Kurek, A. The Use of a Park and Ride System-A Case Study Based on the City of Cracow (Poland). Energies 2020, 13, 3473. [CrossRef]

49. Ibrahim, A.N.H.; Borhan, M.N.; Rahmat, R.A.O.K. Understanding Users' Intention to Use Park-and-Ride Facilities in Malaysia: The Role of Trust as a Novel Construct in the Theory of Planned Behaviour. Sustainability 2020, 12, 2484. [CrossRef] 
50. Macioszek, E.; Świerk, P.; Kurek, A. The Bike-Sharing System as an Element of Enhancing Sustainable Mobility-A Case Study Based on a City in Poland. Sustainability 2020, 12, 3285. [CrossRef]

51. Politis, I.; Fyrogenis, I.; Papadopoulos, E.; Nikolaidou, A.; Verani, E. Shifting to Shared Wheels: Factors Affecting Dockless Bike-Sharing Choice for Short and Long Trips. Sustainability 2020, 12, 8205. [CrossRef]

52. Nikiforiadis, A.; Ayfantopoulou, G.; Stamelou, A. Assessing the Impact of COVID-19 on Bike-Sharing Usage: The Case of Thessaloniki, Greece. Sustainability 2020, 12, 8215. [CrossRef]

53. IMEPLAN, I.M. de P. (Metropolitan P.I., Guadalajara, Mexico) Criterios para la Prueba Piloto relativa a la Implementacion de los Sistemas de Transporte Individual en Red en sus Diferentes Modalidades para el Área Metropolitana de Guadalajara; Vol. Sistemas de Transporte Individual en Red (STIR). p. 12. Available online: https://www.imeplan.mx/en/home (accessed on 16 December 2020).

54. IMEPLAN, I.M. de P. (Metropolitan P.I., Guadalajara, Mexico) Criterios Para La Prueba Piloto Relativos a La Implementación Del Sistema de Bicicletas Sin Anclaje En El Área Metropolitana de Guadalajara. p. 6. Available online: http://imeplan.mx/sites/ default/files/archivos_pdf/Criterios-dockless.pdf (accessed on 16 December 2020).

55. Hancock, L.; Nuttman, S. Engaging Higher Education Institutions in the Challenge of Sustainability: Sustainable Transport as a Catalyst for Action. J. Clean. Prod. 2014, 62, 62-71. [CrossRef]

56. Lien, Y.-N.; Wang, J.-D.; Pan, S.-H.; Ho, C.-Y.; Liao, S.-C. Analysis of Bus Commuting Time of High School Students in Taichung City, Taiwan. Adv. Decis. Sci. 2020, 24, 167-189.

57. Miralles-Guasch, C.; Domene, E. Sustainable Transport Challenges in a Suburban University: The Case of the Autonomous University of Barcelona. Transp. Policy 2010, 17, 454-463. [CrossRef]

58. Nash, S.; Mitra, R. University Students' Transportation Patterns, and the Role of Neighbourhood Types and Attitudes. J. Transp. Geogr. 2019, 76, 200-211. [CrossRef]

59. Pitsiava-Latinopoulou, M.; Basbas, S.; Gavanas, N. Implementation of Alternative Transport Networks in University Campuses: The Case of the Aristotle University of Thessaloniki, Greece. Int. J. Sustain. High. Educ. 2013, 14, 310-323. [CrossRef]

60. Ricciardi, A.M.; Xia, J.; Currie, G. Exploring Public Transport Equity between Separate Disadvantaged Cohorts: A Case Study in Perth, Australia. J. Transp. Geogr. 2015, 43, 111-122. [CrossRef]

61. Soltani, A.; Allan, A.; Nguyen, H.A.; Berry, S. Students' Commuting Pattern from the Viewpoint of Environmentalism: Comparing Australia with China. Int. J. Sustain. High. Educ. 2019, 20, 91-114. [CrossRef]

62. Stein, M.L.; Grigg, J.A. Missing Bus, Missing School: Establishing the Relationship Between Public Transit Use and Student Absenteeism. Am. Educ. Res. J. 2019, 56, 1834-1860. [CrossRef]

63. Whannell, P.; Whannell, R.; White, R. Tertiary Student Attitudes to Bicycle Commuting in a Regional Australian University. Int. J. Sustain. High. Educ. 2012, 13, 34-45. [CrossRef]

64. Cui, B.; Boisjoly, G.; El-Geneidy, A.; Levinson, D. Accessibility and the Journey to Work through the Lens of Equity. J. Transp. Geogr. 2019, 74, 269-277. [CrossRef]

65. Hine, J.; Mitchell, F. Transport Disadvantage and Social Exclusion: Exclusionary Mechanisms in Transport in Urban Scotland; Transport and Society; Routledge: Aldershot, Hants, UK; Burlington, VT, USA, 2016; ISBN 978-0-7546-1847-8.

66. Kathuria, A.; Rajendran, B.G.; Parida, M.; Sekhar, C.R. Examining Walk Access to BRT Stations: A Case Study of Ahmedabad BRTs. Inst. Transp. Eng. ITE J. 2019, 89, 43-49.

67. Özkazanç, S.; Özdemir Sönmez, F.N. Spatial Analysis of Social Exclusion from a Transportation Perspective: A Case Study of Ankara Metropolitan Area. Cities 2017, 67, 74-84. [CrossRef]

68. Miller, E.J. Accessibility: Measurement and Application in Transportation Planning. Transp. Rev. 2018, 38, 551-555. [CrossRef]

69. Ansarey, D. Dropouts at the Tertiary Level in Bangladesh: A Case Study in Asa University Bangladesh. J. Sci. Technol. 2016, 6, 93-110.

70. Centro Mario Molina Proyecto de Movilidad Escolar para el Área Metropolitana de Guadalajara (PROME) Etapa 1; Centro Mario Molina: Guadalajara, Mexico, 2016.

71. Franco Cordero, L. La Movilidad Sostenible En Campus Universitarios: Una Comparación de Las Mejores Prácticas En Estados Unidos y Europa. Aplicabilidad En Universidades Venezolanas. Rev. Fac. Ing. UCV 2014, 29, $23-40$.

72. Sun, C.; Cheng, J.; Lin, A.; Peng, M. Gated University Campus and Its Implications for Socio-Spatial Inequality: Evidence from Students' Accessibility to Local Public Transport. Habitat Int. 2018, 80, 11-27. [CrossRef]

73. García-Morales, M.J. Movilidad urbana en las Universidades del Área Metropolitana de Guadalajara (AMG), México. Un acercamiento a la sustentabilidad; Estudio de caso, ITESO the Jesuit University of Guadalajara: Tlaquepaque, Mexico, 2020.

74. Calonge Reillo, F. Gobernanza neoliberal. Retos para el ordenamiento de las movilidades urbanas. Transp. Y Territ. 2017, 16, 184-200. [CrossRef]

75. UN-Habitat. Estado de las Ciudades de América Latina y el Caribe 2012. Rumbo a una Nueva Transición Urbana; Programa de las Naciones Unidas para los Asentamientos Humanos: Nairobi, Kenya, 2012; Available online: https: / / unhabitat.org/estado-de-lasciudades-de-am\%C3\%A9rica-latina-y-el-caribe-state-of-the-latin-america-and-the-caribbean (accessed on 3 September 2020).

76. IMEPLAN, I.M. de P. (Metropolitan P.I., Guadalajara, Mexico) Home I IMEPLAN. Available online: https://www.imeplan.mx/ en/home (accessed on 16 December 2020). 
77. SEDATU, S. de D.A., Territorial y Urbano, México (Ministry of Agrarian, Territorial and Urban Development (Ministry of Agrarian, Territorial and Urban Development), Mexico; GIZ; Ministerio Federal de Medio Ambiente, Protección de la Naturaleza y Seguridad Nuclear de la República Federal de Alemania; Banco Interamericano de Desarrollo. In Anatomia de la Movilidad en México. Hacia Dónde Vamos; SEDATU: Ciudad de, Mexico, 2018; p. 106.

78. INEGI, I.N. de E. y G. (National I. of S. and G., Mexico) Conjunto de datos Vectoriales de Información Topográfica F13D55 Tesistán. San Francisco Tesistán Escala 1:50 000 Serie III 2015. Available online: https://www.inegi.org.mx/app/biblioteca/ficha. html?upc $=702825270490$ (accessed on 30 November 2020).

79. INEGI, I.N. de E. y G. (National I. of S. and G., Mexico) Conjunto de datos Vectoriales de Información Topográfica F13D65 Guadalajara Oeste Escala 1:50 000 Serie III 2014. Available online: https: / / www.inegi.org.mx/app/biblioteca/ficha.html?upc=70 2825270544 (accessed on 30 November 2020).

80. INEGI, I.N. de E. y G. (National I. of S. and G., Mexico) Conjunto de datos Vectoriales de Información Topográfica F13D75 Jocotepec Escala 1:50 000 Serie III 2015. Available online: https://www.inegi.org.mx/app/biblioteca/ficha.html?upc=702825270605 (accessed on 30 November 2020).

81. INEGI, I.N. de E. y G. (National I. of S. and G., Mexico) Marco Geoestadístico 2019. Available online: https://www.inegi.org.mx/ app/biblioteca / ficha.html?upc=889463776079 (accessed on 30 November 2020).

82. SITEUR, S. de T.E.U. (Urban E.T.S., Guadalajara) SITEUR I Sistema de Tren Eléctrico Urbano. Available online: http:/ / www. siteur.gob.mx/noticias.html (accessed on 26 April 2019).

83. IMEPLAN, I.M. de P. (Metropolitan P.I., Guadalajara, Mexico) Bus network geometry in the Guadalajara Metropolitan Area 2018. Available online: https:/ / sigmetro.imeplan.mx/login (accessed on 10 September 2020).

84. IMEPLAN, I.M. de P. (Metropolitan P.I., Guadalajara, Mexico) SIGmetro. Available online: https://sigmetro.imeplan.mx/mapa (accessed on 26 October 2020).

85. Jalisco, G. del E. de J. (Government of the S. of J). In Encuesta de Satisfacción de los Usuarios del Transporte Público en el Área Metropolitana de Guadalajara; Ministry of Transport: Guadalajara, Mexico, 2018; p. 205. Available online: https://www.polymetrix. $\mathrm{mx} /$ (accessed on 7 October 2020).

86. INEGI, I.N. de E. y G. (National I. of S. and G., Mexico) National Statistical Directory of Economic Units (DENUE, from Its Initials in Spanish). Available online: https:/ / www.inegi.org.mx/app/descarga / (accessed on 27 January 2020).

87. SEP, S. de E.P. (Public E.S). In Principales Cifras Del Sistema Educativo Nacional 2019-2020; Ministry of Education: Ciudad, Mexico, 2020; p. 134. Available online: http:/ / www.planeacion.sep.gob.mx/ (accessed on 26 October 2020).

88. Handy, S.; Niemier, D.A. Measuring Accessibility: An Exploration of Issues and Alternatives-S L Handy, D A Niemeier, 1997. Environ. Plan. A 1997, 29, 1175-1194. [CrossRef]

89. Al Mamun, M.; Lownes, N. A Composite Index of Public Transit Accessibility. J. Public Transp. 2011, 14. [CrossRef]

90. Ben-Elia, E.; Benenson, I. A Spatially-Explicit Method for Analyzing the Equity of Transit Commuters' Accessibility. Transp. Res. Part A: Policy Pract. 2019, 120, 31-42. [CrossRef]

91. Delbosc, A.; Currie, G. Using Lorenz Curves to Assess Public Transport Equity. J. Transp. Geogr. 2011, 19, 1252-1259. [CrossRef]

92. Ghorbanzadeh, M.; Kim, K.; Ozguven, E.E.; Horner, M.W. A Comparative Analysis of Transportation-Based Accessibility to Mental Health Services. Transp. Res. Part D Transp. Environ. 2020, 81, 102278. [CrossRef]

93. Levine, J. A Century of Evolution of the Accessibility Concept. Transp. Res. Part D Transp. Environ. 2020, 83, 102309. [CrossRef]

94. Martinez, L.M.; Viegas, J.M. Assessing the Impacts of Deploying a Shared Self-Driving Urban Mobility System: An Agent-Based Model Applied to the City of Lisbon, Portugal. Int. J. Transp. Sci. Technol. 2017, 6, 13-27. [CrossRef]

95. Yenisetty, P.T.; Bahadure, P. Measuring Accessibility to Various ASFs from Public Transit Using Spatial Distance Measures in Indian Cities. ISPRS Int. J. Geo-Inf. 2020, 9, 446. [CrossRef]

96. CONEVAL, C.N. de E. de la P. de D.S. La Pobreza Urbana en México: Un Enfoque Geoespacial; CONEVAL (Consejo Nacional de Evaluación de la Política de Desarrollo Social), Ciudad de México. 2019, p. 19. Available online: https://www.coneval.org.mx/ Medicion/Documents/Pobreza_urbana/Documentos_metodologicos/Nota_tecnica.pdf (accessed on 19 November 2020).

97. O'Sullivan, D.; Morrison, A.; Shearer, J. Using Desktop GIS for the Investigation of Accessibility by Public Transport: An Isochrone Approach. Int. J. Geogr. Inf. Sci. 2000, 14, 85-104. [CrossRef]

98. OpenStreetMap Contributors Planet Dump. Available online: https:/ / Planet.Osm.Org (accessed on 28 September 2020).

99. SITEUR, S. de T.E.U. (Urban E.T.S., Guadalajara). In LRT_informe_indicador-2020; SEPLAN: Guadalajara, Mexico, 2020.

100. SITEUR, S. de T.E.U. (Urban E.T.S., Guadalajara). In BRT_informe_indicador-2020; SEPLAN: Guadalajara, Mexico, 2020.

101. SITEUR, S. de T.E.U. (Urban E.T.S., Guadalajara). In SITREN_ficha_indicador-2020; SEPLAN: Guadalajara, Mexico, 2020.

102. ITDP, I. for T. and D.Policy.M. Getting TOD Right in Guadalajara. Available online: https:/ /www.itdp.org/2018/04/18/gettingtod-right-guadalajara (accessed on 4 December 2018).

103. Harris, B. Accessibility: Concepts and Applications. In Journal of Transport and Statistics; Bureau of Transportation Statistics, U.S. Department of Transportation: Washington, DC, USA, 2001; pp. 15-30.

104. Nwachukwu, A. Assessment of Passenger Satisfaction with Intra-City Public Bus Transport Services in Abuja, Nigeria. J. Public Transp. 2014, 17, 99-119. [CrossRef]

105. Tahmasbi, B.; Mansourianfar, M.H.; Haghshenas, H.; Kim, I. Multimodal Accessibility-Based Equity Assessment of Urban Public Facilities Distribution. Sustain. Cities Soc. 2019, 49, 101633. [CrossRef] 
106. Vicente, P.; Reis, E. Ex-Regular Users of Public Transport: Their Reasons for Leaving and Returning. J. Public Transp. 2018, 21, 101-116. [CrossRef]

107. Gori, S.; Mannini, L.; Petrelli, M. Equity Measures for the Identification of Public Transport Needs. Case Stud. Transp. Policy 2020, 8, 745-757. [CrossRef]

108. Caywood, M.; Roy, A. Transport Mobility Is a Human Right. Bloomberg CityLab 2018. Available online: https://www.bloomberg. $\mathrm{com} /$ news/articles/2018-10-03/universal-basic-mobility-is-a-human-right (accessed on 9 November 2020).

109. Quevedo García, F.; Asprilla Lara, Y.; González Pérez, M.G. Entropías de la movilidad urbana en el espacio metropolitano de Guadalajara: Transporte privado y calidad del aire. Tecnura Tecnol. Y Cult. Afirmando El Conoc. 2017, 21, 138-140. [CrossRef]

110. Lizárraga, C.; Grindlay, A.L.; Ochoa-Covarrubias, G. Evaluating Public Transport Social Exclusion in Guadalajara, Mexico. In WIT Transactions on the Built Environment; WIT Press: Southampton, UK; Boston, MA, USA, 2020; Volume 200, pp. $195-203$.

111. Gibbons, M. Higher Education Relevance in the 21st Century; World Bank: Paris, France, 1998; p. 73.

112. Jalisco, G.E.J. Government of the S. of J. Mi Macro Periférico. Available online: https://mimacro.jalisco.gob.mx (accessed on 9 December 2020). 